\title{
Managerial Overconfidence and Debt Decisions
}

\author{
Ben Atitallah Rihab, Ben Jedidia Lotfi \\ University of Sfax, Tunisia
}

\begin{abstract}
The application of behavioural theory to corporate finance is now attracting the attention of theoretical work. However, very little rigorous empirical work has been carried out to analyse the desirability of behavioural biases in relation to financing decisions. The main results argue that managerial overconfidence provides an alternative determinant of capital structure. However, many questions remain to be explored, related to overconfidence measures and positive/negative effects of managerial overconfidence. Our paper assumes that the combination of financial theory and behavioural theory leads to better explanatory power. We follow two complementary goals. Firstly, we examine the dynamic trade-off model introducing a behavioural perspective. Secondly, we propose extending the pecking order analysis to incorporate overconfidence in Shyam-Sunder and Myers's model. We use a sample of Tunisian firms and employ panel-data estimation procedures to account for endogeneity and spurious correlation issues. Our results confirm the assumption that manager confidence is positively related to debt level. Overconfident managers underestimate the probability of financial distress and will choose higher levels of debt than they would if they were "rational".
\end{abstract}

Keywords: behavioural corporate finance, overconfidence, dynamic capital structure, leverage, trade-off theory, pecking order

\section{Introduction}

Researches on the capital structure have recently made important progress in the understanding of the evolution of debt levels and choices of financing. The review of this work shows that the tests carried out to explain the funding decisions are focused on three theories: the pecking order theory (Myers \& Majluf, 1984; Autore \& Kovacs, 2003), the trade-off theory (Leary \& Roberts, 2005), and the market timing theory (Baker \& Wurgler, 2007; Greenwood, Hanson, \& Stein, 2010).

The static version of trade-off theory, which suggests the existence of an optimal structure, has been enhanced by dynamic adjustment models that introduce transaction costs. Taking into account the speed and cost adjustment led to the development of the dynamics trade-off (The dynamic trade-off theory: Elsas \& Florysiak, 2011). However, a review of work on partial adjustment models shows that the results obtained are very varied and remain incomplete. Indeed, the adjustment is proving to be rapid in some markets such as Spain (De Miguel \& Pindado, 2001) and America (Flannery \& Rangan, 2006), slower on others, such as Swiss (Gaud, Hoesli, \& Bender, 2007) and France (Kremp, Stöss, \& Gerdesmeier, 1999), and very slow on emerging markets (Haas \& Peeters, 2006).

Ben Atitallah Rihab, assistant professor in Finance, Faculty of Economic Sciences and Management, University of Sfax. Email: Rihab_ba@yahoo.fr.

Ben Jedidia Lotfi, assistant professor, High School of Business, University of Sfax. 
The pecking order theory suggests that the problems of information asymmetry guide firms to establish an order in terms of funding (Myers \& Majluf, 1984). Taking account of the variation in costs of the information asymmetry in time led to the development of the market timing theory. The empirical investigation on this theory shows that the cost of financing equities and financial performance are key determinants of the capital structure (Baker \& Wurgler, 2002; Welch, 2004). Baker, Greenwood, and Wurgler (2003) argued that managers time the maturity of their debt issues to exploit the predictability of bond market returns. That is, they issue short-term debt when the expected return on short-term debt is below the expected return on long-term debt, and vice versa. The authors offer several pieces of evidence in support of their timing hypothesis. However, the review of this work emphasizes that the market timing theory raises a problem of economic interpretation, in particular, to explain the negative relation between historical market-to-book ratios and the debt ratio (Huang \& Ritter, 2009; Butler, Grullon, \& Weston, 2005 ${ }^{1}$ ).

Although the fundamentals are different, the two theories of references (trade-off and pecking order) agree that certain specific factors to the company, such as profitability, size, and opportunities growth, determine the capital structure of firms. However, the theoretical predictions and signs predicted from these frameworks are sometimes different and even contradictory. In contrast, the work that has tried to confront the explanatory power of theories leads to mixed results and fails to decide in favor of a definite theory (Hovakimian, 2004). On the empirical results on the study of power explanatory variables: financial flexibility (Byoun, 2006), debt capacity (Lemmon \& Zender, 2004), and adjustment costs (Leary \& Roberts, 2010) open up a very constructive discussion with regard to financial decision.

More recently, a second line of research which introduces a number of variables from behavioural approach has emerged. The theoretical reflections argue that the irrational behaviour of managers is contributing to study of decision-making, in particular, financial decisions (Gervais, Heaton, \& Odean, 2007). Heaton (2002) modelled the corporate decision-making of optimistic CEOs and argued that managerial optimism is able to lead to managers' pecking order preferences in financing decisions. Hackbarth (2004) showed that overconfidence may help to overcome conflicts between managers and shareholders, related to debt overhang, such as underinvestment and diversion of funds. Malmendier and Tate (2005a) and Malmendier, Tate, and Yan (2011) argued that the investment decisions of overconfident managers are more sensitive to cash-flow, particularly among firms with low debt capacity. The survey results of Ben-David, Graham, and Harvey (2013) find that leverage increases with managerial overconfidence.

Our research is motivated by the scarcity of investigations that took into consideration the cognitive biases to explain a firm's financial decisions (Baker \& Wurgler, 2006) ${ }^{2}$. In this paper, we support the idea that the manager behaviour is a key element in understanding the decision-making process for funding. We will seek to answer the following question: To what extent can behavioural theories complete the "puzzle" of corporate finance and improve their responses in terms of determining financial decision?

We assume that the analysis of manager's behavioural bias neither contradicts nor confirms any of the traditional capital structure theories. In particular, this paper incorporates cognitive variables to study their impact on corporate financial policy.

\footnotetext{
${ }^{1}$ As Butler et al. (2005, p. 1732) put it, "While it is provocative to think that corporate managers may be better able to predict interest rate movements than other market participants... most purchasers of corporate debt are sophisticated investors (for example, banks, insurance companies, and pension funds) who are unlikely to make naïve investment decisions".

${ }^{2}$ Although some theories such as the theory of free cash flow of Jensen (1986) recognize the interaction between financial decisions and manager's behaviour. However, behaviour's modelling is very simplistic.
} 
The remainder of this paper is organized as follows. In Section 2, we review the growing research area of behavioural corporate finance, focusing on articles regarding the intensity of executives' overconfidence and its role in financial decision. The data and sample selection are discussed in Section 3. Our results are presented in Section 4. Finally, some concluding comments are presented in Section 5.

\section{Literature Review: Irrational Capital Structure Decisions}

For over 20 years, there is an incessant appeal to the various humanitarian values and ideological explanation of real phenomena (Zingales, 2000; Glaser, Nöth, \& Weber, 2003; Baker \& Wurgler, 2006). Currently, the finance market (behavioural market) is more conducive to this advanced theme, primarily for the study of anomalies in stock prices (Glaser et al., 2003). A relatively new approach considers behavioural corporate finance and adopts behavioural variables to explain financial decisions in an "irrational" context.

The main themes of behavioural approach are that individuals do not always form beliefs logically, nor do these beliefs convert to decisions in a consistent and rational manner. Psychologists have determined that overconfidence causes people to overestimate their knowledge, underestimate their risks, and exaggerate their ability to control events (Malmendier et al., 2011). Similarly, these studies show that those managers are not immune to overconfidence bias, given the uncertainty of business environment ${ }^{3}$. Overconfident managers tend to consider themselves better than others on different attributes, underestimate the probability of financial distress, and overestimate futures returns.

This section reviews the searches regarding the intensity of executive's overconfidence and its role in capital structure decisions. However, many questions remain to be addressed concerning the overconfidence proxies.

\section{Managerial Overconfidence and Capital Structure}

The overconfidence effect on debt choice. Many studies have analysed the implications of managerial irrationality in capital structure and in particular debt decision (Heaton, 2002; Hackbarth, 2004; Gervais et al., 2007).

Hackbarth (2004) modelled the effect of managerial overconfidence in a trade-off model of capital structure. In the first version, he considered the case where the manager attempts to maximise firm value and established a positive relationship between the manager's bias and the use of debt. Indeed, the overconfident manager sees debt as the source of funding less subject to the undervaluation problem. In addition, an overconfident manager believes that the volatility of cash flow process is lower than it really is and, therefore, he perceived the chances of bankruptcy as remote comparing to what they really are. Given the low perceived bankruptcy costs, he might choose a higher debt leverage ratio. In the second version, Hackbarth (2004) introduced agency costs related to the problem of free cash-flows of Jensen (1986). The results confirm that an irrational leader chooses a higher level of debt than a rational manager. The increased reliance on debt is explained by the resolution of problems associated with free cash flows.

Hackbarth (2008) considered a wider menu of effects of managerial overconfidence. He found that overconfident managers choose higher debt levels, issue new debt more often, and tend to time capital structure decisions. Hackbarth (2008) considered the effect of managerial overconfidence on bondholder/shareholder conflicts. He demonstrated that overconfidence can mitigate underinvestment problems, but can exacerbate risk-shifting problems.

\footnotetext{
${ }^{3}$ Cooper, Woo, and Dunkelberg (1988) made a survey about some US managers and they found that managers generally thought that the success probability of other firms is only $59 \%$, but this probability goes up to $81 \%$ when it relates to their own firms. This suggested that it is an evidence for managers to be overconfident.
} 
Fairchild (2009) examined the impact of manager's behavioural bias on the capital structure by introducing joint agency conflicts and the problems of information asymmetry (moral hazard). In the first case, he considered the signalling role of debt in an asymmetric information model, without moral hazard problems. Overconfidence led managers to overestimate the probability of good states and to underestimate the probability of bankruptcy. This resulted in excessive use of welfare-reducing debt. In the second case, he considered the commitment role of debt in a moral hazard model, without asymmetric information problems. In this case, the effect of overconfidence on firm value is ambiguous. Overconfidence has both positive and negative effects on shareholder wealth. That is, overconfidence induces higher managerial effort, but may also result in excessive value-reducing debt levels. Fairchild (2009) concluded that overconfidence may provide a rationale for the empirical observation that many companies take on excessive debt at some time. Similarly, the optimism pushes the manager to respect the shareholder's interests and to preserve their reputations to work "employability" (Malmendier \& Tate, 2005a).

Barros and Silveira (2008) tested the relationship between the degree of leaders' optimism and overconfidence and debt financing over the period of 1998-2003 based on a sample of 135 Brazilian firms. The authors found that the coefficients of the cognitive variables influence positively the level of debt. The coefficients obtained vary between 0.02 and 0.13 , and are all significant at $5 \%$.

Ben-David, Graham, and Harvey (2007) related the miscalibration of chief financial officers (CFOs) (the measure of overconfidence) to a wide range of corporate decisions, including corporate financing. They empirically tested whether CFO optimism affects corporate policies via 25 quarterly surveys between March 2001 and March 2007 on senior executives, mostly CFOs. Using a survey-based proxy for overconfidence, Ben-David et al. (2007) argued that companies with overconfident CFOs invest more, have higher debt leverage, pay out fewer dividends, and use proportionally more long-term than short-term debt.

Ang, Cole, and Lawson (2010) presented the first study to quantify the extent of individual owner effects and to provide support for incorporating personal risk characteristics as a fundamental component in traditional capital structure theory. The results show that firm leverage is positively related to the owner age, business experience, sophistication, number of financial institutions used by the owner, sales of the firm, and whether or not the owner uses computers for business purpose or pledges collateral. In addition, the authors showed that firm leverage is negatively related to the age of the firm and the ratio of return on assets.

The pecking order theory: A behavioural perspective. The pecking order theory established an order of preference for financial sources (Myers \& Majluf, 1984). Managers prefer internal to external financing and, when there is an inadequate amount of internal funds, debt financing is preferred to equity financing. The pecking order preference is explained by asymmetric information between the firms and the capital market (Myers, 1984). Recent theoretical work shows that a specification of personal characteristic will also lead to managers' pecking order preference (Heaton, 2002; Camerer, 2003; Lin, Hu, \& Chen, 2008). The results of these studies raise an important question: How can we adopt the behavioural pecking order theory?

Graham and Harvey (2001) argued that "the preference [of the survey executives] for pecking-order-like behaviour might be driven by managerial optimism" (p. 219). Baker and Wurgler (2006) showed that the psychology of leadership influences the evaluation of alternative funding. Assessing the various alternatives is subject to the attitude of the leader as the optimism that increases the likelihood of success of the event or the trust that influences the levels of risk (Baker \& Wurgler, 2006). 
Heaton's (2002) model assumes that overconfident managers believe that a firm's future performance is rosier than it actually is. In systematically overestimating the probability of good firm performance versus the capital market's outlook, optimistic managers will have a tendency to perceive the market as undervaluing their own firm. Since riskier securities are more sensitive to managers' probability beliefs and are thus more undervalued by the market, optimistic managers will therefore prefer to rely on internal funding rather than issue risky securities to finance their needs. When these internal funds are not forthcoming, managers will choose debt financing first over equity. As a result, optimistic managers will display a pecking order preference when making financing decisions. More recently, Malmendier and Tate (2005b) and Fairchild (2005) led to similar conclusions and showed that the funding risk (bond issues) is more sensitive to the beliefs and judgments of leaders.

Besides Heaton (2002), Lin et al. (2008) concluded that the pecking order hypothesis performs better when managers are optimistic. Using listed Taiwanese companies, Lin et al. (2008) found a strong positive relation between the sensitivity of net debt issues to financing deficits and managerial optimism. That is, the sensitivities between the net debt issues and financing deficits for optimistic managers are larger than those for non-optimistic ones ${ }^{4}$.

Bigus (2003) postulated that the financing choices are not studied in parallel but successively. This procedure is called sequential analysis and subject to "subdivision" bias. He provided a new approach to the pecking order theory by emphasizing the issue that investors and entrepreneurs may have heterogeneous beliefs on firms' future returns.

Similarly, according to a behavioural study, Camerer, Loewenstein, and Prelec (2005) argued that the theory of pecking order can be explained by the manager's temporal myopia.

In conclusion, the results show that firms with overconfident managers maintain higher debt ratios and longer debt maturity. However, many questions remain to be addressed relating to overconfidence measures.

\section{Overconfidence Measures}

Naturally, the cognitive biases of interest are not directly observable. In this kind of study, one of the most difficulties is to measure managerial overconfidence.

The stock option holding measures used in Malmendier and Tate (2005a) and Malmendier et al. (2011) are based on premises similar to those of insider trading measures and have similar advantages. Malmendier and Tate used Hall and Murphy (2002) option exercise model to determine a rational executive's optimal option exercise policy. They consider an executive to be optimistic if she chooses not to exercise an option when the Hall and Murphy model says she should. The authors translate this logic into three measures of overconfidence. The "longholder" measure is a CEO-fixed effect, which implies that overconfidence is considered as a stable personality trait rather than the cognitive bias it really is. A second measure of overconfidence, "Holder 67", is allowed to vary from year to year which alleviates this particular problem. Finally, if a manager purchases additional firm stock despite their already high exposure to risk, he/she is regarded as overconfident.

Lin et al. (2008) constructed an alternative measure of optimism by studying management earnings forecasts. The rationale for using forecasts is simply that if managers are optimistic in their assessment of future outcomes, they should be more likely to provide a forecast that is overestimated. If the numbers of upward-biases are more than that of downward-biases, the managers are regarded as overconfident.

\footnotetext{
${ }^{4}$ The difference between the two groups of firms (led by an optimistic manager/headed by a pessimistic manager) is significant at $1 \%$.
} 
Ben-David et al. (2013) used survey data collected over a five-year period to ascertain their proxy for manager confidence. The authors drew their overconfidence measures based on the idea that the confidence bounds around point estimates reflect the individual probability distribution that respondents attribute to the stochastic process in question. Each quarter, for the past five years, they have surveyed US CFOs and asked them to predict one- and ten-year market equity returns and also to provide $80 \%$ confidence bounds around their estimates. They used the narrowness of the individual probability distributions for the stock market returns as a measure for the confidence of respondents. They quantified the degree to which CFOs are calibrated and examined the cross-sectional determinants of overconfidence. Consistently with the psychological literature, Ben-David et al. (2013) indicated that overconfidence is associated with both personal traits and firm culture. In particular, the authors documented that managerial overconfidence increases with the degree of skill and education but decreases with professional experience.

The various overconfidence measures defined by literature can be summarized as follows (see Table 1).

Table 1

Different Measures of Overconfidence Used in Empirical Studies

\begin{tabular}{|c|c|c|}
\hline Author & Sample and study's context & Measure of overconfidence \\
\hline Malmendier and Tate (2005b) & $\begin{array}{l}477 \text { largest US companies between } 1980 \\
\text { and } 1994\end{array}$ & $\begin{array}{l}\text { Managers' stock option exercise } \\
\text { decisions: CEOs are considered } \\
\text { "overconfident" if they do not exercise } \\
\text { highly in the money stock options }\end{array}$ \\
\hline Malmendier and Tate (2008) & $\begin{array}{l}\text { List of the winners of CEO awards } \\
\text { between } 1975 \text { and } 2002\end{array}$ & $\begin{array}{l}\text { Press portrayal: the press publications } \\
\text { consider CEOs to be overconfident }\end{array}$ \\
\hline Lin et al. (2008) & $\begin{array}{l}\text { Companies listed on the Taiwan Stock } \\
\text { Exchange (TSE) during the period of } \\
1989-2004\end{array}$ & $\begin{array}{l}\text { Upward-biased earnings forecasts by } \\
\text { CEOs }\end{array}$ \\
\hline Barros and Silveira (2008) & $\begin{array}{l}153 \text { non-financial Brazilian firms for the } \\
\text { period of } 1998-2003\end{array}$ & $\begin{array}{l}\text { An entrepreneur/non-entrepreneur } \\
\text { classification }\end{array}$ \\
\hline Oliver (2005) & University of Michigan from 1978 to 2004 & $\begin{array}{l}\text { Booming index: The average of } \\
\text { the past } 12 \text { months' Consumer Sentiment } \\
\text { Index }\end{array}$ \\
\hline Glaser et al. (2003) & $\begin{array}{l}835 \text { non-financial German firms between } \\
2001 \text { and } 2006\end{array}$ & $\begin{array}{l}\text { The insider stock transaction behavior of } \\
\text { managers reported to the German Federal } \\
\text { Financial Supervisory Authority }\end{array}$ \\
\hline Ben-David et al. (2007) & $\begin{array}{l}\text { US corporate CFOs for the period of } \\
2001-2006\end{array}$ & $\begin{array}{l}\text { Miscalibration level: CFOs who display a } \\
\text { narrow confidence interval when asked to } \\
\text { predict future stock returns are considered } \\
\text { overconfident }\end{array}$ \\
\hline
\end{tabular}

\section{Empirical Methods and Methodological Discussion}

Since the seminal work of Modigliani and Miller (1958), much research effort has been directed at understanding firms' capital structure. Reference theories are pecking order and trade-off theories. These theories argue implicit assumptions that managers and investors are rational decision makers who want to get maximum utility. We have shown (in Section 2) that recent researches adopt the explanatory power of cognitive variables. However, empirical studies are scarce due to unsuitable ways to evaluate irrational behaviour of managers. Using hypothetico-deductive approach, we study the empirical relationship between management overconfidence and leverage of Tunisian firms. 


\section{Sample and Period of Study}

Our sample consists of 55 Tunisian companies belonging to industrial, commercial, and service industries. Financial institutions were excluded because their funding policies are very different from those of non-financial companies. The main sources of data in this study are the stock market, the offices of accountants and companies. The data collected are mainly accounting data gathering balance sheets, income statements, depreciation schedules, and statements of financial flows. The necessary adjustments have been made such as the reinstatement of leasing and expected effects and outstanding. Our study period extends from 1997 until 2001.

\section{Determinants of Capital Structure}

The specific-firm determinant: Trade-off vs. pecking order. The trade-off and the pecking order are the principal theories, which have studied the structure of capital. The factors underlying the financial structure lie primarily in profitability, size, growth opportunities, and the structure of assets (see Table 2).

Table 2

Summary of Key Variables of Capital Structure and the Signs Predicted

\begin{tabular}{|l|l|l|l|}
\hline Variable & Pecking order & Trade-off & Reference works \\
\hline Profitability & - & + & Titman (1984), Baker and Wurgler (2002), and Flannery and Rangan (2006) \\
\hline Tangibility & + & + & Rajan and Zingales (1998), Kremp et al. (1999), and Hovakimian (2006) \\
\hline Size & $+/-$ & + & Rajan and Zingales (1998), Leary and Roberts (2010) \\
\hline $\begin{array}{l}\text { Future investment } \\
\text { opportunities }\end{array}$ & + & - & Rajan and Zingales (1998), Huang and Ritter (2009) \\
\hline
\end{tabular}

Measure of managerial overconfidence. Under the first section, we presented a review of the literature on the various proxies to measure cognitive biases, including overconfident leaders (CEO's share holding for Malmendier \& Tate, 2008; upward-biased earnings forecasts by CEOs for Lin et al., 2008). However, all these proxies are not available in the Tunisian context.

Consistent with Barros and Silveira (2008), we propose different proxies for managerial optimism/overconfidence, mainly based on the manager's status as an entrepreneur or non-entrepreneur.

A related theoretical perspective argues that entrepreneurs are more likely to suffer from various overconfidence biases. Several reasons have been proposed for the overconfidence nature of entrepreneurs. In fact, the entrepreneurs operate in settings where information and evidence are highly uncertain.

Empirical research has found that overconfidence manifests strongly in the entrepreneurial environment. Cooper et al. (1988) surveyed entrepreneurs asking "what are the odds of your business succeeding?". They observed that entrepreneurs exhibited substantial optimism, in that they reported their odds of success both significantly higher than base rates and substantially better than their self-reported odds for similar businesses ${ }^{5}$. They concluded that the observed optimism was likely caused by ex-post decision bolstering, in that once the entry into self-employment had been made, entrepreneurs were likely to justify this choice by believing that their choice would lead to success.

\footnotetext{
${ }^{5}$ Cooper et al. (1988) found that $81 \%$ of the 2,994 founders in their sample rated the chances that their ventures would succeed at over 70\%; and, incredibly, about one third of founders in this sample believed that such likelihood was fully $100 \%$. The same study revealed unrealistic optimism in the founders sampled: an average $81 \%$ probability of success for their own business dwarfed the $59 \%$ probability of success they saw for businesses like theirs.
} 
Similarly, Busenitz and Barney (1997) studies show that entrepreneurs are much more optimistic in their assessment of management. The authors used a sample of 124 entrepreneurs, that is, individuals who started and managed their own business, and 95 professional managers from large firms, with middle- to upper-level responsibilities. The results of Busenitz and Barney (1997) show that the entrepreneurs are likely to be too confident. In addition, Pinfold (2001) confirmed that optimism persists because entrepreneurs self-servingly attribute favourable outcomes to their own ability.

The arguments and evidence listed in this section suggest that managers who are also entrepreneurs display the biases of optimism and overconfidence more frequently or more pronouncedly than other managers. Assuming that this is the case, we use the distinction between firms managed by "entrepreneurs" and those managed by "non-entrepreneurs" (or professional managers) as the main strategy to empirically identify the presence of these biases. Taking into account these arguments, we suggest that:

Managers who are also entrepreneurs display the biases of optimism and overconfidence more frequently or more pronouncedly than other managers.

We define a dummy variable, coded $M A N_{i t}$, with $M A N_{i t}=1$, if the manager of the $i$ th firm in the $t$ thear was classified as an entrepreneur (overconfident/optimistic individual). CEO or chairman in year $t$ holds more than $50 \%$ of its common shares. $M A N_{i t}=0$ if he/she was classified as a non-entrepreneur ("rational" or less overconfident/optimistic person).

The classification of the manager as an entrepreneur or non-entrepreneur may capture their degree of overconfidence and optimism.

\section{Specification Models}

In this paper, we develop a financing model in which managerial overconfidence and traditional determinant of capital structure (firm-specific factor) combine to affect the manager's debt decision.

Pecking order behavior. By using a specification of Shyam-Sunder and Myers (1999), we test the pecking order by examining the sensitivities between the net debt issues and the financing deficits. We apply the methodology initiated by Shaym-Sunder and Myers (1999) and Frank and Goyal (2003) to measure the "financing deficit".

Consistent with the behavioural approach, we introduce in the model the interaction between overconfidence and financing deficit to check if the net-debt-issue/financing-deficit sensitivities for optimistic managers are larger than those for non-optimistic ones.

We consider the following regression setup:

$$
\triangle D E B T_{i t}=\beta_{1}+\beta_{2} D E F_{i t}+\beta_{3} D E F * M A N_{i t}+\xi_{i t}
$$

\footnotetext{
${ }^{6} D E F_{i t}=D I V_{i t}+I N V_{i t}+\Delta W_{i t}-C F_{i t}=\Delta D_{i t}+\Delta E_{i t}$, where the components in this identity are $(i$ indexes firm, and $t$ indexes fiscal year): $\Delta W_{i t}=$ Change in working capital, computed as the change in operating working capital plus the change in cash and cash equivalents plus the change in current debt; $D I V_{i t}=$ Cash dividends; $I N V_{i t}=$ Net investments, computed as the sum of capital expenditures, increase in investments, acquisitions, other use of funds net of the sale of product, plant, and equipment (PPE) and net of the sale of investment; $C F_{i t}=$ Cash flow after interest and taxes, computed as income before extraordinary items, plus depreciation and amortization, plus extraordinary items and discontinued operations, plus deferred taxes, plus equity in net loss, minus earnings, plus other funds from operations, and plus gain (loss) from sales of PPE and other investments; $\Delta E_{i t}=$ Net equity issued, equal to sales of common stock minus stock repurchases; and $\Delta D_{i t}=$ Net debt issued, equal to long-term debt issuance minus long-term debt reduction.
} 
where $D E B T_{i t}$ is the endogenous variable, which represents the book ratio of total debt of the company $i$ for the period $t ; M A N_{i t}$ is the dummy variable indicating the status of the manager (entrepreneur/non-entrepreneur) and captures overconfidence bias; $D E F^{*} M A N$ measures the interaction of optimism and the financing deficit; $\beta_{2}$ represents the net-debt-issue/financing-deficit sensitivities of non-optimistic managers. The empirical validation of pecking order theory suggests that the funding gap should be totally financed by debt. Therefore, the coefficient $\beta_{2}$ must be equal to unity; and $\beta_{3}$ stands for the sensitivities of overconfident managers.

In a second step, we follow Frank and Goyal $(2003 ; 2005)$ to attach the variables that include the tangibility of assets, profitability, size, and growth opportunities in Model 1 (M1). The combination of these variables with the financing deficit has better explanatory power on debt (Chen \& Zhao, 2006).

$$
D E B T_{i t}=\beta_{1}+\beta_{2} D E F_{i t}+\beta_{3} M A N_{i t}+\beta_{4} S T R U C_{i t}+\beta_{5} R E N T_{i t}+\beta_{6} S I Z E_{i t}+\beta_{7} P R O_{i t}+\xi_{i t}
$$

STRUC, RENT, SIZE, and PRO are respectively, the tangibility of assets, profitability, size of the firm, and growth opportunities. The measures adopted for these variables are defined in Appendix A.

Dynamic trade-off financing behaviour. We contend that extending traditional capital structure theory to account for the managerial traits can tighten some important gaps between known theoretical predictions and unresolved empirical facts. Following Hackbarth (2004), we incorporate well-documented managerial overconfidence into a trade-off model of capital structure to study their impact on corporate financial policy.

Following Rajan and Zingales (1998), we construct a linear regression model as follows:

$$
D E B T_{i t}=\alpha_{0}+\alpha_{1} M A N_{i t}+G_{i t}^{\prime} \alpha_{2}+\lambda_{t}+\xi_{i t}
$$

where:

$D E B T_{i t}$ : Endogenous variable, which represents the ratio of total financial debt of the company $i$ for the period $t$;

$M A N_{i t}:$ Dummy variable indicating the status of the manager (entrepreneur/non-entrepreneur) and captures overconfidence bias;

$G_{i t}^{\prime}$ : A raw vector of conventional variables used in Rajan and Zingales (1998) that include tangibility of assets (STRUC), profitability (RENT), size (SIZE), and growth opportunities (PRO);

$\lambda_{t}$ : Temporal dummy variable;

$\xi_{i t}$ : Error term.

According to dynamic trade-off theory, firms have long run target leverage and adjust the gap between actual and target leverage each year. We retain a partial adjustment model of capital structure (Flannery \& Rangan, 2006):

$$
D E B T_{i t}=(1-\delta) D E B T_{i t-1}+\alpha_{1} M A N_{i t}+G_{i t}^{\prime} \alpha_{2}+\lambda_{t}+\xi_{i t}
$$

The adjustment speed of leverage ( $\delta$ ) is bounded between zero and one. When is near one of these boundaries, it goes rapidly adjusted to the long run target leverage and is near zero, the adjustment is few.

Using panel data, Lööf (2004) applied a nonlinear, least square methodology to estimate the parameters in a setup similar to ours in Model 4 (M4). However, this methodology leads to biased and inconsistent estimators because error terms tend to be correlated with lagged leverage, $D E B T_{i t-1}$.

In order to avoid this problem, we apply the dynamic panel data and generalized method of moments (GMM) with Balestra and Nerlove's instruments. They proved that estimation provides consistent parameter 
estimates by utilizing instruments that can be obtained from orthogonality conditions. Concerning the instruments, we report the Sagan statistic, which tests the over-identifying restrictions. It must be noted that the Sargan test rejects too often in presence of heteroskedasticity.

\section{Empirical Analysis Results}

Appendix A presents the definitions of all variables introduced in our models. Appendix B reports descriptive statistics of the explanatory variables. Appendix $\mathrm{C}$ reports the correlation matrix.

\section{The Pecking Order Behaviour}

We make the assumption that our models contain specific individual effect. Consequently, we assume that the best specification of our models is the random-effect estimator. In addition, the fixed-effect model poses the problem of multicollinearity because our models contain dummy variables. Table 3 summarizes the results of OLS and GLS regressions.

Table 3

Summary of the Main Results of the Regressions

\begin{tabular}{|c|c|c|c|c|}
\hline \multicolumn{5}{|c|}{ Panel A: Results of estimating (M1) } \\
\hline Variable & OLS & GLS & OLS & GLS \\
\hline Const. & $\begin{array}{c}0.274^{* * *} \\
(0.013)\end{array}$ & $\begin{array}{c}0.252^{* * *} \\
(0.008)\end{array}$ & $\begin{array}{c}0.237^{* * *} \\
(0.024)\end{array}$ & $\begin{array}{l}0.216^{* * *} \\
(0.006)\end{array}$ \\
\hline$D E F$ & $\begin{array}{l}-0.224^{* * * 4} \\
(0.098)\end{array}$ & $\begin{array}{l}-0.148^{* * *} \\
(0.037)\end{array}$ & $\begin{array}{l}-0.222^{* *} \\
(0.098)\end{array}$ & $\begin{array}{l}-0.135^{* * *} \\
(0.031)\end{array}$ \\
\hline$D E F^{*} M A N$ & $\begin{array}{l}0.255^{* * *} \\
(0.104)\end{array}$ & $\begin{array}{l}0.231^{* * *} \\
(0.097)\end{array}$ & $\begin{array}{c}0.250^{* *} \\
(0.104)\end{array}$ & $\begin{array}{l}0.205^{* * *} \\
(0.093)\end{array}$ \\
\hline TEND & $e_{2}$ & - & $\begin{array}{c}0.012^{*} \\
(0.007) \\
\end{array}$ & $\begin{array}{c}0^{0.014} 4^{* * *} \\
(0.001)\end{array}$ \\
\hline$R^{2}$ & 0.022 & 0.035 & 0.033 & 0.059 \\
\hline Fischer & 3.176 & 4.990 & 3.145 & 4.288 \\
\hline Prob. ( $F$-statistic) & 0.043 & 0.007 & 0.025 & 0.002 \\
\hline \multicolumn{5}{|c|}{ Panel B: Results of estimating (M2) } \\
\hline Variable & OLS & GLS & OLS & GLS \\
\hline Const. & $\begin{array}{l}0.348^{* * *} \\
(0.046)\end{array}$ & $\begin{array}{c}0.240^{* *} \\
(0.095)\end{array}$ & $\begin{array}{l}0.308^{* * *} \\
(0.048)\end{array}$ & $\begin{array}{c}0.190^{*} \\
(0.113)\end{array}$ \\
\hline STRUC & $\begin{array}{l}0.154^{* * *} \\
(0.015)\end{array}$ & $\begin{array}{l}0.144^{* * *} \\
(0.047)\end{array}$ & $\begin{array}{c}0.149^{* * * *} \\
(0.014)\end{array}$ & $\begin{array}{l}0.147^{* * *} \\
(0.046)\end{array}$ \\
\hline$R E N T$ & $\begin{array}{c}0.305^{*} \\
(0.153) \\
\end{array}$ & $\begin{array}{c}0.805^{* *} \\
(0.355)\end{array}$ & $\begin{array}{c}0.265^{* *} \\
(0.155)\end{array}$ & $\begin{array}{c}0.793^{* * *} \\
(0.353)\end{array}$ \\
\hline SIZE & $\begin{array}{l}-0.010^{* * *} \\
(0.002)\end{array}$ & $\begin{array}{l}-0.005 \\
(0.006)\end{array}$ & $\begin{array}{l}-0.009^{* * *} \\
(0.002)\end{array}$ & $\begin{array}{l}-0.004 \\
(0.006)\end{array}$ \\
\hline$M A N$ & $\begin{array}{l}0.062^{* * *} \\
(0.015)\end{array}$ & $\begin{array}{c}0.055^{* * *} \\
(0.014)\end{array}$ & $\begin{array}{l}0.061^{* * *} \\
(0.012)\end{array}$ & $\begin{array}{c}0.055^{* * *} \\
(0.014)\end{array}$ \\
\hline$P R O$ & $\begin{array}{l}-0.042^{* * *} \\
(0.008)\end{array}$ & $\begin{array}{l}-0.039 \\
(0.039)\end{array}$ & $\begin{array}{l}-0.036^{* * *} \\
(0.008)\end{array}$ & $\begin{array}{l}-0.039 \\
(0.039)\end{array}$ \\
\hline$D E F$ & $\begin{array}{l}-0.073 \\
(0.049) \\
\end{array}$ & $\begin{array}{l}-0.127 \\
(0.079)\end{array}$ & $\begin{array}{l}-0.067 \\
(0.054)\end{array}$ & $\begin{array}{l}-0.132^{*} \\
(0.077)\end{array}$ \\
\hline TEND & 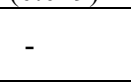 & - & $\begin{array}{c}0.007^{* * *} \\
(0.001)\end{array}$ & $\begin{array}{c}0.012^{* * *} \\
(0.001)\end{array}$ \\
\hline$R^{2}$ & 0.206 & 0.181 & 0.206 & 0.109 \\
\hline Fischer & 11.652 & 3.971 & 9.902 & 4.666 \\
\hline Prob. ( $F$-statistic $)$ & 0.000 & 0.000 & 0.000 & 0.000 \\
\hline
\end{tabular}

Notes. Dependent variable: $D E B T .{ }^{*}:$ Significant at $10 \% ;{ }^{* *}$ : Significant at $5 \% ;{ }^{* * *}$ : Significant at $1 \%$. Values in parentheses are standard errors. 
Adjusted $R^{2}$ indicates that the explanation power of model is low, particularly for the GLS regressions. In all regressions, Fischer test is significant at the $1 \%$ level and allows us to refuse the hypothesis $\mathrm{H}_{0}$ according to which the total of the introduced variables explained in the system is meaningless.

In panel $\mathrm{A}$, the coefficient of variable $D E F$ has a negative sign and is not significant. Originally, Shaym-Sunder and Myers (1999) suggested that when firms follow the pecking order, a unity slope coefficient should be observed. However, our results do not confirm the predictions of the theory of pecking order, particularly in the presence of cognitive arguments.

We confirm that overconfident managers prefer debt to finance the deficit financing. In particular, the coefficient of the interaction of optimism and the financing deficit $\left(D E F^{*} M A N\right)$ is positive and significant at $1 \%$. The positive sign of this variable is maintained in the OLS and GLS regressions. In addition to the reasoning of Myers and Majluf (1984), our result makes a contribution by providing evidence of an alternative source from which financing policies are impacted. However, the coefficient of variable $D E F$ has a sign contradictory to theoretical hypothesis.

Temporal effect (TEND) is significant at $1 \%$ level. The period of our study was marked by events that affect firm's financing decisions.

In panel $\mathrm{B}$, in all regressions the coefficient of $M A N$ is positive and significant at $1 \%$ level. Our results confirm the assumption that manager's confidence is positively related to debt level. An overconfident manager overestimates his/her ability, and underestimates financial distress costs (Heaton, 2002). Similarly, this positive relationship is consistent with the empirical studies (Malmendier, Tate, \& Yan, 2005).

The tangibility $(S T R U C)$ is always positively correlated with leverage, and all coefficients are significant at the $1 \%$ level of significance. This result supports the prediction of the trade-off theory that the debt capacity increases with the proportion of tangible assets on the balance sheet.

Size (SIZE) is significant at the $1 \%$ level and negatively related to leverage. If we criticize the size at the magnitude of the information asymmetry, our results confirmed the pecking order wards. Under this theory, less information asymmetry implies preference for equity relative to debt, thus applying a negative correlation between size and leverage. This result contradicts the idea that size is a proxy for a low probability of default, as suggested by the trade-off theory. In particular, Booth, Aivazian, Demirguc-Kunt, and Maksimovic (2001) indicated that when the debt capacity is increased, bigger firm size will lower monitoring cost for managing and reducing moral hazard risk, adverse selection problem. For the GLS regressions, the variable (SIZE) becomes insignificant, but it retains its negative sign.

Our results also show that profitable firms use more debt. Indeed, the variable profitability $(R E N T)$ is positive and significant. This result is consistent with trade-off predictions because of the tax advantage. This finding contradicts the predictions of the pecking order theory and the majority of empirical studies (Frank \& Goyal, 2004; Malmendier \& Tate, 2008).

The variable $P R O$ is negative and significant in OLS regressions. This result is consistent with the trade-off theory and the agency cost's perspective (Miller, 1977). However, it contradicts the assumptions of the pecking order theory.

\section{Dynamic Trade-off Financing Behaviour}

Table 4 reports the results of estimating equations (M3) and (M4) with the general method of moments (GMM) dynamic panel data estimator. 
Table 4

Key Results of Estimations

\begin{tabular}{|c|c|c|c|c|}
\hline \multirow{2}{*}{ Variable } & \multicolumn{2}{|c|}{ Static model } & \multicolumn{2}{|c|}{ Dynamic model } \\
\hline & \multicolumn{2}{|c|}{ GLS } & \multicolumn{2}{|c|}{ GLS } \\
\hline \multirow{2}{*}{ Const. } & $0.225^{* *}$ & 0.176 & 0.052 & 0.020 \\
\hline & $(0.106)$ & $(0.124)$ & $(0.098)$ & $(0.092)$ \\
\hline \multirow{2}{*}{$D E B T(-1)$} & & & $0.448^{* * *}$ & $0.457^{* * *}$ \\
\hline & - & - & $(0.168)$ & $(0.163)$ \\
\hline \multirow{2}{*}{ STRUC } & $0.152^{* * *}$ & $0.155^{* * *}$ & $0.133^{* * *}$ & $0.133^{* * *}$ \\
\hline & $(0.047)$ & $(0.047)$ & $(0.030)$ & $(0.029)$ \\
\hline \multirow{2}{*}{$R E N T$} & $0.743^{* *}$ & $0.728^{* * *}$ & 0.114 & 0.109 \\
\hline & $(0.356)$ & $(0.352)$ & $(0.154)$ & $(0.150)$ \\
\hline \multirow{2}{*}{$S I Z E$} & -0.005 & -0.004 & 0.0009 & 0.001 \\
\hline & $(0.006)$ & $(0.006)$ & $(0.004)$ & $(0.004)$ \\
\hline \multirow{2}{*}{$M A N$} & $0.052^{* * *}$ & $0.052^{* * *}$ & $0.029^{* * *}$ & $0.028^{* * *}$ \\
\hline & $(0.017)$ & $(0.016)$ & $(0.012)$ & $(0.012)$ \\
\hline \multirow{2}{*}{$P R O$} & -0.037 & -0.037 & -0.003 & -0.003 \\
\hline & $(0.036)$ & $(0.036)$ & $(0.016)$ & $(0.015)$ \\
\hline \multirow{2}{*}{ TEND } & & $0.012^{* * *}$ & \multirow[t]{2}{*}{100.} & $0.007^{*}$ \\
\hline & - & $(0.002)$ & & $(0.004)$ \\
\hline$R^{2}$ & 0.169 & 0.195 & 0.485 & 0.504 \\
\hline Fischer test & 4.034 & 4.741 & - & - \\
\hline Prob. (Fischer) & 0.001 & 0.000 & - & - \\
\hline Instrument rank & - & - & 9 & 10 \\
\hline \multirow{2}{*}{ Sargan test } & \multirow{2}{*}{-} & \multirow[b]{2}{*}{-} & 5.572 & 5.581 \\
\hline & & & $P$-value & $P$-value $=0.0613$ \\
\hline
\end{tabular}

Notes. Dependent variable: DEBT. ": Significant at 10\%; ": Significant at 5\%; " : Significant at 1\%. Values in parentheses are standard errors.

The adjusted $R^{2}$ indicates that the explanation power of model is satisfactory, in particular for the dynamic model. Sargan test statistics refer to the null hypothesis that the over-identifying restrictions are valid.

In static regressions, the coefficient of $M A N$ is positive and significant at $1 \%$ level. Our results confirm the assumption that manager's confidence is positively related to debt level. An overconfident manager overestimates his/her ability, and underestimates financial distress costs (Heaton, 2002). Similarly, this positive relationship is consistent with the empirical studies (Malmendier et al., 2011).

The tangibility (STRUC) is always positively correlated with leverage, and all coefficients are significant at the $1 \%$ level of significance. This result supports the prediction of the trade-off theory that the debt capacity increases with the proportion of tangible assets on the balance sheet. Size (SIZE) is significant at the $1 \%$ level and negatively related to leverage. Our results confirmed the pecking order wards. Under this theory, less information asymmetry implies preference for equity relative to debt, thus applying a negative correlation between size and leverage. The profitability (RENT) has a positive sign, however, it becomes insignificant. Similarly, the variable $P R O$ is not significant. These results do not comply with the theoretical and empirical predictions.

The time dimension is significant for all regressions. The introduction of this variable does not change the previous results and improve the $R^{2}$ of models.

In dynamic regressions, our result shows expressive and significant coefficients at the $1 \%$ level for the lagged dependent variable $\left(D E B T_{t-1}\right)$. This variable focuses on the costs of adjustment. In the Tunisian context, the speed of adjustment is rapid and comparable to American level ( 0.41 estimated by Shyam-Sunder \& Myers, 1999) and German level (0.47 estimated by Kremp et al., 1999). 
With the exception of the variable $R E N T$, which becomes not significant, the estimation of dynamic model presents similar results in static model. The dynamic model shows the relevance of the temporal dimension. Indeed, the variable TEND presents a significant coefficient.

\section{Conclusion}

The objective of this research is to study the impact of behavioral biases on the capital structure. In particular, overconfident managers lead to increased probability of bankruptcy. Therefore, he/she prefers debt to equity financing.

In our study, we empirically analyzed the link between managerial optimism and capital structure. Taking into account the measurement difficulties and specificities of our context, our overconfidence measure is based on the manager's status (as an entrepreneur or non-entrepreneur). This proposition is supported by theories and solid empirical evidence showing that entrepreneurs tend to display these cognitive biases more frequently than other managers (Barros \& Silveira, 2008).

In this paper, we include "overconfidence" variable in addition, potential determinants of capital structure as suggested by the traditional pecking order and trade-off approaches. In the sample of Tunisian firms, our empirical results show that "overconfidence" variable is positive and significant at debt level. In static as well as dynamic formulations, overconfident managers underestimate the probability of financial distress and will choose higher levels of debt than they would if they were "rational". The other determinants of capital structure, profitability, size, growth opportunities and tangibility, are significant.

Our result illustrates that corporate financial policies may be better understood if the analysis also accounts for managerial bias. Our analysis focuses on managerial overconfidence; however, it can be enhanced by the introduction of other managerial characteristics (optimism, risk aversion, and altruism). Indeed, several authors consider the role of emotional aspects such as emotions or moods in terms of decision-making (Azouzi \& Jarboui, 2012). Managers can opt for a decision which is a selfish or altruistic posture (Hermalin \& Isen, 2000; Morck, Shleifer, \& Vishny, 1988).

However, there are some suggestions for future research:

(1) Future prospects should focus on other proxies of overconfidence through a non-binary approach. A major challenge for future research is to measure overconfidence through a non-binary approach. We try to measure the overconfidence by miscalibration test which has the advantage of measuring the intensity of this bias;

(2) In addition to the relationship between debt decisions and overconfidence, several issues deserve more attention as the effect of overconfidence on firm value that remains ambiguous;

(3) Future research should incorporate the effects of corporate governance from the behavioural perspective to analyze their impacts on corporate decisions. Recent examples of studies in this direction are Brown and Sarma (2007) and Goel and Thakor (2008);

(4) Last but not least, can we speak of an optimal level of overconfidence (Bessière, 2007)?

\section{References}

Ang, J., Cole, R., \& Lawson, D. (2010). The role of owner in capital structure decisions: An analysis of single-owner corporations. Journal of Entrepreneurial Finance, 14(3), 1-36.

Autore, D., \& Kovacs, T. (2003). The pecking order theory and time-varying adverse selection costs. Working Paper, Virginia Tech. Azouzi, M. A., \& Jarboui, A. (2012). CEO emotional bias and capital structure choice. Bayesian network method. Journal of Business Excellence and Management, 2(2), 47-70. 
Baker, M., \& Wurgler, J. (2002). Market timing and capital structure. The Journal of Finance, 57(1), 1-32.

Baker, M., \& Wurgler, J. (2006). Investor sentiment and the cross-section of stock returns. Journal of Finance, 61(4), $1645-1680$.

Baker, M., \& Wurgler, J. (2007). Investor sentiment in the stock market. Journal of Economic Perspectives, 21(2), 129-152.

Baker, M., Greenwood, R., \& Wurgler, J. (2003). The maturity of debt issues and predictable variation in bond returns. Journal of Financial Economics, 70(2), 261-291.

Barros, L. A. B. C., \& Silveira, A. D. M. (2008). Overconfidence, managerial optimism, and the determinants of capital structure. Revista Brasileira de Financas, 6(3), 293-335.

Ben-David, I., Graham, J. R., \& Harvey, C. R. (2007). Managerial overconfidence and corporate policies. Working Paper, Duke University, Fuqua School of Business.

Ben-David, I., Graham, J. R., \& Harvey, C. R. (2013). Managerial miscalibration. The Quarterly Journal of Economics, 128(4), 1547-1584.

Bessière, V. (2007). Excès de confiance des dirigeants et décisions financières: une synthèse. Revue Finance Contrôle Stratégie, 10(1), 39-66.

Bigus, J. (2003). Heterogeneous beliefs, moral hazard, and capital structure. Schmalenbach Business Review, 55(2), 136-160.

Booth, L., Aivazian, V., Demirguc-Kunt, A., \& Maksimovic, V. (2001). Capital structures in developing countries. The Journal of Finance, 56(1), 87-130.

Brown, R., \& Sarma, N. (2007). CEO overconfidence, CEO dominance and corporate acquisitions. Journal of Economics and Business, 59(5), 358-379.

Busenitz, L. W., \& Barney, J. B. (1997). Differences between entrepreneurs and managers in large organizations: Biases and heuristics in strategic decision-making. Journal of Business Venturing, 12(1), 9-30.

Butler, A. W., Grullon, G., \& Weston, J. P. (2005). Can managers forecast aggregate market returns? Journal of Finance, 60(2), 963-986.

Byoun, S. (2006). Why do some firms go debt free? Working Paper, Baylor University.

Camerer, C. (2003). The behavioural challenge to economics: Understanding normal people. Paper presented at the Federal Reserve Bank of Boston Meeting on "How Humans Behave", June 8-10.

Camerer, C., Loewenstein, G., \& Prelec, D. (2005). Neuroeconomics: How neuroscience can inform economics. Journal of Economic Literature, 43(1), 9-64.

Chen, L., \& Zhao, X. (2006). On the relation between the market-to-book ratio, growth opportunity, and leverage ratio. Finance Research Letters, 3(4), 253-266.

Cooper, A. C., Woo, C. Y., \& Dunkelberg, W. C. (1988). Entrepreneurs' perceived chances for success. Journal of Business Venturing, 3(2), 97-108.

De Miguel, A., \& Pindado, J. (2001). Determinants of capital structure: New evidence from Spanish panel data. Journal of Corporate Finance, 7(1), 77-99.

Elsas, R., \& Florysiak, D. (2011). Heterogeneity in the speed of adjustment toward target leverage. International Review of Finance, 11(2), 181-211.

Fairchild, R. (2005). The effect of managerial overconfidence, asymmetric information, and moral hazard on capital structure decisions. The ICFAI Journal of Behavioural Finance, 2(4).

Fairchild, R. (2009). Managerial overconfidence, moral hazard problems, and excessive life-cycle debt sensitivity. Investment Management and Financial Innovations, 6(3), 35-42.

Flannery, M. J., \& Rangan, K. P. (2006). Partial adjustment toward target capital structures. Journal of Financial Economics, 79(3), 469-506.

Frank, M. Z., \& Goyal, V. K. (2003). Testing the pecking order theory of capital structure. Journal of Financial Economics, 67(2), 217-248.

Frank, M. Z., \& Goyal, V. K. (2005). Trade-off and pecking order theories of debt. Working Paper, University of British Columbia.

Gaud, P., Hoesli, M., \& Bender, A. (2007). Debt-equity choice in Europe. International Review of Financial Analysis, 16(3), 201-222.

Gervais, S., Heaton, J. B., \& Odean, T. (2007). Overconfidence, investment policy, and manager welfare. Working Paper.

Glaser, M., Nöth, M., \& Weber, M. (2003). Behavioral finance. Sonderforshcungsbereich 504 "Rationalitätskonzepte, Entscheidungsverhalten und ökonomische Modellierung".

Goel, A. M., \& Thakor, A. V. (2008). Overconfidence, CEO selection, and corporate governance. The Journal of Finance, 63(6), 2737-2784. 
Graham, J. R., \& Harvey, C. R. (2001). The theory and practice of corporate finance: Evidence from the field. Journal of Financial Economics, 60(2-3), 187-243.

Greenwood, R., Hanson, S., \& Stein, J. C. (2010). A gap-filling theory of corporate debt maturity choice. The Journal of Finance, 65(3), 993-1028.

Haas, R., \& Peeters, M. (2006). The dynamic adjustment towards target capital structures of firms in transition economies. Economics of Transition, 14(1), 133-169.

Hackbarth, D. (2004). Determinants of corporate borrowing: A behavioral perspective. Working Paper, Indiana University.

Hackbarth, D. (2008). Managerial traits and capital structure decisions. Journal of Financial and Quantitative Analysis, 43(4), 843-881.

Hall, B. J., \& Murphy, K. J. (2002). Stock options for undiversified executives. Journal of Accounting and Economics, 33(1), 3-42.

Heaton, J. B. (2002). Managerial optimism and corporate finance. Financial Management, 31(2), 33-45.

Hermalin, B. E., \& Isen, A. M. (2000). The effect of affect on economic and strategic decision making. Econometric Society World Congress 2000 Contributed Papers 1136.

Hovakimian, A. (2004). The role of target leverage in security issues and repurchases. Journal of Business, 77(4), 1041-1072.

Hovakimian, A. (2006). Are observed capital structures determined by equity market timing? Journal of Financial and Quantitative Analysis, 41(1), 221-243.

Huang, R., \& Ritter, J. R. (2009). Testing theories of capital structure and estimating the speed of adjustment. Journal of Financial and Quantitative Analysis, 44(2), 237-271.

Jensen, M. C. (1986). Agency costs of free cash flow, corporate finance, and takeovers. American Economic Review, 76(2), 323-329.

Kremp, E., Stöss, E., \& Gerdesmeier, D. (1999). Estimation of a debt function: Evidence from French and German firm panel data. In A. Sauve, M. Scheuer, \& H. Friderichs (Eds.), Corporate finance in Germany and France (pp. 140-191). Frankfurt am Main: Deutsche Bundesbank.

Leary, M. T., \& Roberts, M. R. (2005). Do firms rebalance their capital structures? Journal of Finance, 60(6), 2575-2619.

Leary, M. T., \& Roberts, M. R. (2010). The pecking order, debt capacity, and information asymmetry. Journal of Financial Economics, 95(3), 332-355.

Lemmon, M. L., \& Zender, J. F. (2004). Debt capacity and tests of capital structure theories. Working Paper, University of Utah and University of Arizona.

Lin, Y., Hu, S., \& Chen, M. (2008). Testing pecking order prediction from the viewpoint of managerial optimism: Some empirical evidence from Taiwan. Pacific-Basin Finance Journal, 16(1-2), 160-181.

Lööf, H. (2004). Dynamic optimal capital structure and technical change. Structural Change and Economic Dynamics, 15(4), 449-468.

Malmendier, U., \& Tate, G. (2005a). Does overconfidence affect corporate investment? CEO overconfidence measures revisited. European Financial Management, 11(5), 649-659.

Malmendier, U., \& Tate, G. (2005b). CEO overconfidence and corporate investment. The Journal of Finance, 60(6), 2661-2700.

Malmendier, U., \& Tate, G. (2008). Who makes acquisitions? CEO overconfidence and the market's reaction. Journal of Financial Economics, 89(1), 20-43.

Malmendier, U., Tate, G., \& Yan, J. (2005). Corporate financial policies with overconfident managers. Paper presented at the 8th Annual Texas Finance Festival.

Malmendier, U., Tate, G., \& Yan, J. (2011). Overconfidence and early-life experiences: The effect of managerial traits on corporate financial policies. Journal of Finance, 66(5), 1687-1733.

Miller, M. H. (1977). Debt and taxes. The Journal of Finance, 32(2), 261-275.

Modigliani, F., \& Miller, M. H. (1958). The cost of capital, corporation finance and the theory of investment. American Economic Review, 48(3), 261-297.

Morck, R., Shleifer, A., \& Vishny, R. W. (1988). Management ownership and market valuation: An empirical analysis. Journal of Financial Economics, 20, 293-315.

Myers, S. C. (1984). The capital structure puzzle. The Journal of Finance, 39(3), 574-592.

Myers, S. C., \& Majluf, N. S. (1984). Corporate financing and investment decisions when firms have information that investors do not have. Journal of Financial Economics, 13(2), 187-221.

Oliver, B. R. (2005). The impact of management confidence on capital structure. Paper presented at the AAANZ and Asia Finance Association conferences in New Zealand. Working Paper, School of Finance and Applied Statistics, Australian National University, Canberra, Australia. 
Pinfold, J. F. (2001). The expectations of new business founders: The New Zealand case. Journal of Small Business Management, 39(3), 279-285.

Rajan, R., \& Zingales, L. (1998). Debt, folklore, and cross-country differences in financial structure. Journal of Applied Corporate Finance, 10(4), 102-107.

Shyam-Sunder, L., \& Myers, S. C. (1999). Testing static tradeoff against pecking order models of capital structure. Journal of Financial Economies, 51, 219-244.

Titman, S. (1984). The effect of capital structure on a firm's liquidation decision. Journal of Financial Economics, 13(1), $137-151$. Welch, I. (2004). Capital structure and stock returns. Journal of Political Economy, 112(1), 106-131.

Zingales, L. (2000). In search of new foundations. Journal of Finance, 55(4), 1623-1653.

\section{Appendix A}

Table A1

Definitions of Variables

\begin{tabular}{|c|c|}
\hline Variable name & Definition \\
\hline Total debt ratio $(D E B T)$ & Total liabilities/total assets \\
\hline Financing deficit $(D E F)$ & Cash dividends + Net investment + Change in working capital - Internal cash flow \\
\hline Cash dividends $(D I V)$ & Dividends paid + Director and employee bonus paid \\
\hline Net investment $(I N V)$ & $\begin{array}{l}\text { Sale (purchase) short-term investment (investment purpose) }+\Delta \text { of derivative for } \\
\text { investment }+ \text { Sale long-term investment }+ \text { Purchase long-term investment }+ \text { Sale fixed } \\
\text { assets }+ \text { Purchase fixed assets }+ \text { Cash paid-merging }\end{array}$ \\
\hline Change in working capital $(\Delta W)$ & $\begin{array}{l}\Delta W=\text { Decrease (increase) in } A / R \text { and } N / R+\text { Decrease (increase) inventories }+ \text { Other } \\
\text { adjustment operating }+ \text { Change in cash and cash equivalents }\end{array}$ \\
\hline Internal cash flow $(C)$ & $\begin{array}{l}\text { Net income current }+ \text { Non-cash extraordinary depreciation }+ \text { Depreciation }+ \text { Amortization }+ \\
\text { Investment income }+ \text { Investment loss }+ \text { Cash dividend long-term investment }+ \text { Loss (gain) } \\
\text { disposal short-term investment }+ \text { Decrease (increase) short-term investment trading }+ \\
\text { Decrease (increase) of derivative for trade }+ \text { Loss (gain) disposal fixed assets }+ \text { Loss (gain) } \\
\text { disposal long-term investment + Provision (reversal of reserve) }\end{array}$ \\
\hline Managerial overconfidence $(M A N)$ & $\begin{array}{l}\text { Dummy variable equals to } 1 \text { for the CEOs if the manager is classified as overconfident and } \\
\text { equals to } 0 \text { if not }\end{array}$ \\
\hline Size $(S I Z E)$ & Log of annual sales \\
\hline Profitability $(R E N T)$ & Return on asset: Earnings before interests and depreciation \\
\hline Tangibility of assets $(S T R U C)$ & Total fixed assets/total assets \\
\hline Growth opportunities $(P R O)$ & Ratio of capital expenditures to total assets \\
\hline
\end{tabular}

\section{Appendix B}

Table B1

Descriptive Statistics of Variables

\begin{tabular}{lccccccc}
\hline Statistic & STRUC & DEF & PRO & \multicolumn{1}{l}{ SIZE } & MAN & \multicolumn{1}{c}{ RENT } & DEBT \\
\hline Mean & 0.511083 & 0.130611 & 0.060538 & 15.76951 & 0.509091 & 0.078368 & 0.583505 \\
Median & 0.507601 & 0.100702 & 0.053700 & 15.92321 & 1.000000 & 0.085839 & 0.597699 \\
Maximum & 0.957083 & 0.972632 & 0.261776 & 20.42754 & 1.000000 & 0.594930 & 1.110795 \\
Minimum & 0.103754 & -0.389897 & 0.000000 & 10.99585 & 0.000000 & -0.301998 & 0.063223 \\
Std. dev. & 0.204921 & 0.160749 & 0.048481 & 1.956709 & 0.500829 & 0.097249 & 0.207654 \\
Skewness & 0.090038 & 2.282683 & 1.049286 & -0.228320 & -0.036370 & -0.445481 & -0.317345 \\
Kurtosis & 2.027122 & 11.12633 & 4.140847 & 2.688189 & 1.001323 & 7.654937 & 2.583068 \\
Jarque-Bera & 11.21678 & 995.4972 & 65.37595 & 3.503335 & 45.83335 & 257.3800 & 6.607605 \\
Probability & 0.003667 & 0.000000 & 0.000000 & 0.173484 & 0.000000 & 0.000000 & 0.036743 \\
Sum & 140.5477 & 35.91803 & 16.64806 & $4,336.616$ & 140.0000 & 21.55111 & 160.4639 \\
Sum sq. dev. & 11.50600 & 7.080255 & 0.644005 & $1,049.066$ & 68.72727 & 2.591294 & 11.81492 \\
Obs. & 275 & 275 & 275 & 275 & 275 & 275 & 275 \\
\hline
\end{tabular}


Appendix C

Table C1

Matrix Correlation

\begin{tabular}{lcccccc}
\hline Variable & STRUC & DEF & PRO & \multicolumn{1}{l}{ SIZE } & \multicolumn{1}{l}{ MAN } & RENT \\
\hline STRUC & 1.000000 & -0.007149 & 0.028729 & -0.004132 & 0.046090 & -0.063933 \\
DEF & -0.007149 & 1.000000 & 0.392632 & 0.086435 & 0.112820 & 0.028117 \\
SIZE & -0.004132 & 0.086435 & 0.125288 & 1.000000 & 0.248845 & -0.064927 \\
MAN & 0.046090 & 0.112820 & 0.342022 & 0.248845 & 1.000000 & -0.100284 \\
PRO & 0.082935 & -0.031380 & 0.020133 & -0.117273 & 0.138526 & -0.043927 \\
RENT & -0.063933 & 0.028117 & -0.052348 & -0.064927 & -0.100284 & 1.000000 \\
\hline
\end{tabular}

